\title{
THE COURTS COMPETENT TO DEAL WITH INDIVIDUAL LABOR DISPUTES. PROPOSALS TO REFORM THE SYSTEM
}

\section{Onica Chipea}

\section{Lavinia Onica-Chipea}

Faculty of Law, the Law and Administration Department

University of Oradea, Oradea, Romania

*Correspondence: Lavinia Onica-Chipea, University of Oradea,

26 General Magheru St., Oradea, Romania

E-mail: laviniachipea@yahoo.com

\section{Abstract:}

The paper proposes that following the doctrinal analysis of judicial practice, the comparative law in terms of a specific study performed using sociological methods of investigation, to formulate proposals for amendments to the Romanian legislation regarding the courts that are empowered to resolve individual labor conflicts.

These proposals aim on the one hand the need to establish labor and social security tribunals and on the other hand panels up to resolve individual labor disputes involving legal assistance at both hierarchical levels, which express a deliberative vote.

Keywords: courts, labor and social security tribunals, legal aid, deliberative vote.

\section{Introduction}

The doctrine and jurisprudence analysis shows that justice which solves the principle of individual labor disputes has specific characteristics in a position to outline specific labor jurisdiction of the Romanian legal system. This particularity lies in the existence of a distinct system of judicial bodies which resolves labor disputes, the material and territorial competence of the courts in matters of labor disputes presenting features, some of them presenting departures from the rules of the common law, a party in a labor dispute and, especially, specifies the duration of time that the person is standing interest, requested by the legislator to bring proceedings which are expressly governed by special rules; the conduct of the trial and judgment in matters of labor disputes, is governed by rules which derogate from the common law, aiming mainly two objectives, namely: ensuring that the principle of celerity in resolving labor disputes, and the employee protection, considered to be the disadvantaged party for a labor dispute.

In certain situations, due to the manifest conditions in which some aspects of the social life are carried out, certain waivers from the normal procedure are imposed by establishing special procedures ${ }^{1}$, means rules that make general rules and regulations if they do not contravene the imperative rules ${ }^{2}$.

On the courts competent to resolve individual labor disputes in the Romanian legal system, the provisions of art. 208 of Law. 62/2011 of the Social Dialogue expressly provides that general jurisdiction belong to courts. Thus, following the amendment of the Code of Civil Procedure, the court was given "unlimited jurisdiction" in terms of resolution of conflicts of rights, individual labor disputes, from this point, the court resolving only by exception a

\footnotetext{
${ }^{1}$ L. R. Popoviciu, Minor's criminal liability, ProUniversitaria Publishing House, Bucharest, 2012, pg. 196.

2 R. Gh. Florian, L. R. Popoviciu, The obligation to refund of employees, in A.I.J.J.S no. 2/2010, www.juridicaljournal.univagora.ro.
} 
number of lawsuits and claims ${ }^{3}$ what expressly were assigned by law. In the complete tribunals and specialized wards for labor disputes and social security, which are formed with the participation of a judge and two judicial assistants, as representatives of the parties to the employment relations? ${ }^{4}$

Appeals against the decisions of the Court of first instance are assigned to the jurisdiction of the Courts of Appeal. And in these instances work also specialized sections or panels in labor disputes and social security panel of three judges, without the participation of legal aid in the law. ${ }^{5}$

Based on existing legal reality and briefly reiterated previously in full compliance with relevant aspects of legal practice in the field of conflict resolution work both nationally and in the Bihor County, the opinions expressed by the doctrine of comparative law regulations subject of our research, we believe that the legislature, in consultation with the social partners should consider further in his lawmaking the following:

A. To introduce a legal provision expressly providing for establishment of special courts for labor and social security, with general jurisdiction and the settlement of labor disputes, or individual labor conflicts and work through special legislation to establish concrete way of putting into place

In fact, on this proposal, we rally an opinion based doctrine that believes that the idea of establishing specialized courts work and social security ${ }^{6}$, which was dropped after the change, in 2005, of Law no. 304/2004 on judicial organization, which would have been "very positive" because it effectively ensured the greater specialization of judges in the areas of labor law and respective social security by maintaining their stability courts mentioned.

We support the idea of bringing other arguments above, considered essential to support them. Thus, a simple foray into the history of labor legislation in the Romanian legal system provides viable examples on the organization and operation by specialized courts, labor courts, which operated the next room working, competent to settle labor disputes pursuant to Law for the establishment and organization of labor jurisdiction in 1933.

Also, the comparative law provides many examples in this regard. Thus, we recall briefly the existence of three major systems work in practice jurisdiction of different countries: specialized courts, which are modern forms of employment litigation and have become in recent years an increasingly large audience, which can be in turn the two types: autonomous organ of labor jurisdiction, common law system in Germany and England, and each tribunal specific work included in the system of courts of common law, common law systems of France, Italy, Poland, systems of labor jurisdiction by conventional organs, an important means of resolving labor disputes, specifically America and the Swedish law, recourse to ordinary courts.

The necessity for the establishment of specialized labor courts was expressly emphasized in a study prepared and implemented for this purpose. ${ }^{7}$ Thus, using a sociological investigation methods, namely focus group we aim to fill legislative and judicial practice perspective, the subject of our analysis, the specific opinions collected through sociological

\footnotetext{
${ }^{3}$ Țiclea, Al., Labor Law. University Course, Legal Universe Publishing House Bucureşti, 2007, pp.431-432.

4 Art.55 from Law no. 304/2004 regarding judicial organization, republished, was modified in this sense, through Law no. 202/2010.

${ }^{5}$ Art.54 paragraph. 2 the second thesis from Law no. 304/2004 regarding judicial organization, republished.

${ }^{6}$ Belingrădeanu, S., General Considerations and Critical Observations Regarding the Specialized Labor and Social Security Courts and the Judicial Assistants in the Light of Law no. 304/2004 Regarding Judicial Organization in Law I nr. 9/2004, p.13.

${ }^{7}$ Onica Chipea, L., Is legislative intervention required in the jurisdiction of the Romanian legal labor system?, in Agora International Journal of Juridical Sciences - The consequences of European integration on the legal system in Romania, vol.V, No.I, 2010.
} 
methods, from those who actually work in practice with this procedure, namely lawyers, legal advisors, judges, members of the panel to resolve labor disputes.

Thus there were recorded from concrete experience of the respondents, proposed amending legislation reviewed for the purposes of establishing specialized courts in labor disputes, composed of representatives of employers and trade unions, involving exceptional cases only divergence or remedies career judges, namely the creation of specialized courts in labor disputes in line with historical experience of the Romanian legal system.

We believe that the arguments supporting, entitled, such a legislative proposal are:

- It is necessary that the trend shown shy, of specialization of labor jurisdiction in the Romanian legal system, built on the specifics of the legal work, born after concluding an employment contract to be finalized by establishing specialized courts, or employment tribunals;

- Judges who make up these specialized courts prove a sufficient job in that field; knowing labor issues, thereby enjoying a full independence and autonomy;

- A specialized court can give judgment leaner, faster and less expensive;

- Ordinary courts, or courts and courts of appeal, in which currently operates full employment and social security will be relieved by the large number of cases of this kind, particularly social security and thus effectively channeling human and material resources, to resolve other causes, consider that argument because relevant and that recent legislative changes included labor disputes of jurisdiction, civil servants work, reality will help increase the number of cases subject to this jurisdiction;

- On hierarchical levels that would require the establishment of specialized courts consider that the first step would be sufficient, and material reasons, to establish labor courts with unlimited jurisdiction in resolving individual labor conflicts, following that the review against the decisions of the first instance court, courts of common law, that the Court of Appeal, however, would require that, for completing reform of labor jurisdiction panels to resolve individual labor disputes the Court of Appeal is constituted with the participation of judicial assistants, people with experience in labor relations, which have deliberative role within this structure, something to which we will return below.

B. We also believe that for completing reform of labor jurisdiction regulating the composition of panels required to settle at first instance and on appeal to labor disputes and social security with the participation of legal aid and grant them a deliberative vote

The starting point in formulating this legislative proposal is the current laws governing that institution, namely Article 55 of Law no. 304/2004 on judicial organization, republished, modified by Law nr.202/2010, article 54 par. 2 second sentence of Law. 304/2004 on judicial organization, republished.

Thus, we believe that invoking arguments consist of all doctrine and judicial practice ideas considered for continuation or completion of the process of specialization of labor jurisdiction of the Romanian legal system is necessary to:

- Appeal panels for settling labor disputes and social security be formed both career judges ( 3 under current legislation) and in two judicial assistants, court-like configuration which solves cases background (right panels tribunal common, which according to previous legislative proposal will be replaced by specialized courts work)

- Judicial assistants that make up the panel of judges to express a deliberative vote.

a. Regarding the establishment of a court of appeal panels with the participation of judicial assistants, we consider appropriate to support the argument that judicial assistants, in their capacity as representatives of the parties to the employment relationship, the employee and employer that participates in resolving individual labor conflicts, completing deliberative structure and that their legal knowledge with absolutely necessary, they have "the vocation of 
reality," ${ }^{8}$ i.e. knowledge production labor in various sectors. Moreover, their presence in panels work is supported by the spirit of labor jurisdiction in the Romanian legal system, designed jurisdiction to intervene in conflicts settlement with tools specific to, arising from the particular nature of the employment relationship. Participation panels, legal aid work are one of the principles on labor jurisdiction of the Romanian legal system.

It also provides numerous examples comparative law, among which the German system, the jurisdiction courts to hear labor disputes, that courts held three hierarchical levels (Labor Courts of First Instance, Courts of Appeal for labor issues, the Federal Court Labor), are composed of professional judges, career and legal aid doctrine and judges appointed honorary or assessors, who have the same privileges as professional judges. ${ }^{9}$

b. Regarding the need of awarding the judicial assistants the deliberative vote, noting that arguments the following ideas expressed in doctrine and practice review, which we rally and offered many examples of comparative law:

- The advisory vote, granted legal aid under current Romanian legislation is "the most blatant and serious regulatory failure Law. 304/2004" because the European Court of Human Rights and regulations issued by the Council of Europe and Romanian fundamental act itself after review, creates the possibility of participation in specialized instances of people outside the judiciary, which can "do and they do, in equally, with judges the act of justice." 10 Also it was appreciated rightly in the doctrine" , "that there is a contradiction in terminis between membership of the panel and for some deliberative and consultative vote for others, since the judgment is delivered to all members, who make part of a deliberative structure, as the jury can not only have a consultative vote on the other hand everyone is entitled by law to be part of a panel of judges of a court", even if not judge career must "speak right" and "not to express a simple opinion, which basically anyone can do." ${ }^{.2}$ It is proposed to give up the legal aid panels participation to resolve individual labor disputes, keeping them still being considered as "clearly critical" and "both unnecessary, harmful and unnatural" and their presence seems that judges are actually "pseudo-magistrates" must necessarily consult judicial assistants in order to fulfill their mission.

- One of the conclusions of their study, cited above is that it is absolutely necessary assigning roles deliberative full legal aid work to justify their presence. Otherwise, as actually existing governing laws, judicial assistants have only an advisory role and can even be absent from court. ${ }^{13}$ Some of the experts interviewed supported the idea that would require the establishment of specialized courts in labor disputes, composed only of representatives of employers and trade unions that judicial assistants, involving exceptional only in cases of dispute or appeal, career judges, idea according to existing regulation in comparative law, specifically the French legal system, which, as we have developed throughout the paper, Prud'homme Councils are composed only of representatives of the parties to the employment relationship, courts career can be called only in case of a tie, that third parties separates votes.

\section{Conclusions}

Assuming that the Romanian legislator would accept legislative proposals previously held the picture of labor law would have the following appearance:

\footnotetext{
${ }^{8}$ Ştefănescu, I.,T., Theoretical and Practical Treaty of Labor Law, Legal Universe Publishing House, Bucureşti, 2011, p.881.

${ }^{9}$ Weiss, M., The System of Labor Courts in Germany, in Romanian Journal of Labor Law, nr. 3/2004, p.99.

${ }^{10}$ Țiclea, Al., Treaty of Labor Law, Legal Universe Publishing House, Bucureşti, 2007, p. 959.

${ }^{11}$ Belingrădeanu S., cit. work, in Law I nr. 9/2004, p.17.

12 Corsiuc, O., M., Consideration referring of the institution of judicial asistants in the light of the new Regulations of Law no. 304/20004, in Romanian Journal of Labor Law, nr.4/2004, p. 82;

${ }^{11}$ Onica Chipea, L., cit.work, p.10.
} 
A. Throughout the Law no. 304/2004 on judicial organization to insert a mandatory legal provision stipulating the establishment of special courts for labor law. Specialized courts are courts without legal personality, operating in the counties and in Bucharest and usually office in the county capital. Specialized courts will take jurisdiction of the court in cases where established;

B. The social dialogue and other specific sources of labor law (collective agreements, internal regulations) contain provisions regarding:

1. Implementation of the Law no. 304/2004 on judicial organization on the establishment of special courts for labor;

2. Including legal provision which states that judicial assistants participate in panels to resolve individual labor disputes both in substance and in appeal and expresses a deliberative vote.

\section{Bibliography}

Popoviciu L. R., Minor's criminal liability, ProUniversitaria Publishing House, Bucharest, 2012;

Ştefănescu, I.,T., Theoretical and Practical Treaty of Labor Law, Legal Universe Publishing House, Bucharest, 2011;

Onica Chipea, L., Is legislative intervention required in the jurisdiction of the Romanian legal labor system?, in Agora International Journal of Juridical Sciences - The consequences of European integration on the legal system in Romania, vol.V, No.I, 2010;

R. Gh. Florian, L. R. Popoviciu, The obligation to refund of employees, in A.I.J.J.S no. 2/2010, www.juridicaljournal.univagora.ro;

Țiclea Al. Labor Law. University Course, Legal Universe Publishing House Bucharest, 2007;

Țiclea, Al., Treaty of labor law, Legal Universe Publishing House, Bucharest, 2007;

Belingrădeanu S. General Considerations and Critical Observations Regarding the Specialized Labor and Social Security Courts and the Judicial Assistants in the Light of Law no. 304/2004 Regarding Judicial Organization in Law I nr. 9/2004;

Corsiuc, O., M., Consideration referring of the institution of judicial asistants in the light of the new Regulations of Law no. 304/20004, in Romanian Journal of Labor Law, nr.4/2004;

Weiss, M., The System of Labor Courts in Germany, in Romanian Journal of Labor Law, nr. 3/2004. 